\title{
Poverty and conflict
}

Zoe Marks

\section{October 2016}

Poverty and conflict are widely understood to be closely interconnected; with poverty making countries more prone to civil war, and armed conflict weakening governance and economic performance, thus increasing the risk of conflict relapse (Goodhand 2001). The selected readings in this pack move beyond reductive and harmful assumptions about 'pathologies' of poverty to examine the latest research into the poverty-conflict nexus. Earlier studies identified macro-level factors that made countries more likely to experience armed conflict. For example, low per capita income and large populations correlate with civil war, whereas ethnic and religious diversity does not make countries more prone to conflict (Fearon \& Laitin 2003). Newer research examines the processes and mechanisms that precipitate and shape violence on the ground.

At the state level, poverty can lower resilience to conflict by weakening government institutions, stripping capacity for public goods provision, and limiting the projection of power and authority, whether soft or coercive. Poverty also compounds vulnerability to insurgency at the individual and community level by lowering the opportunity cost of mobilising for violence. High rates of unemployment and inequality, combined with low levels of education and development, are thought to soften the ground for recruitment and provide motives to fight (Humphreys \& Weinstein 2008). ${ }^{1}$ These individual correlates of poverty often follow systematic patterns that lead to 'horizontal inequalities'. Horizontal inequalities occur when members of ethnic, religious, or other identity groups have unequal access to public goods, opportunities and resources. Group-level inequalities can generate social and economic polarisation that increases the risk of violent conflict (Østby 2008; Stewart 2009).

Of course, these dynamics alone do not start wars. Political grievances and conflict proneness are most likely to lead to violence-from terrorism to civil war-when poverty and inequality combine with repression, particularly in anocracies, regimes that are neither strongly democratic, nor wholly autocratic (Abadie 2004; Mousseau et al. 2003). Yet,

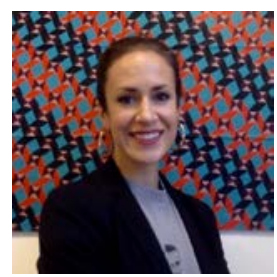

Zoe Marks is Chancellor's Fellow at the University of Edinburgh, where she is Director of the University's Global Development Academy and the School of Social and Political Science's MSc in African Studies. Her research focuses on the internal dynamics of violence and civil war, gender relations, and post-conflict development. She is currently leading comparative research projects on peacebuilding and post-conflict trajectories in Democratic Republic of Congo, Liberia, Nigeria, and Sierra Leone.

\footnotetext{
${ }^{1}$ See also the GSDRC Reading Pack on 'Jobs, unemployment, and violence': http://www.gsdrc.org/professional-dev/jobs-unemployment-and-violence/.
}

Reading packs are commissioned by the UK Government's Department for International Development (DFID) for independent study and professional development use. They are intended to be thought-provoking introductions to emerging issues and debates within the subject areas they cover. The views expressed are those of the author, and do not necessarily reflect the opinions of GSDRC, its partner agencies or DFID. (C) DFID Crown Copyright 2016. Licensed under the Open Government Licence: www.nationalarchives.gov.uk/doc/open-government-licence 
governance can also mitigate the link between poverty and conflict. Resource governance plays a key role in shaping countries' economic and structural vulnerability to conflict (Ross 2004; Thies 2010). While social welfare spending, particularly on education and healthcare, and stable aid flows reduce the risk of war, aid shocks and excessive military spending increase its likelihood (De Ree \& Nillesen 2009; Nielsen et al. 2011; Savun \& Tirone 2011; Taydas \& Peksen 2012). Similarly, economic shocks, such as the 2008 spike in global food prices, can spark social unrest that escalates into armed conflict in vulnerable political settings (Blattman \& Miguel 2010; Lagi et al. 2011).

Once conflict breaks out, it hits the poor the hardest: social welfare is depleted as goods and services are diverted to the war effort; rural infrastructure is destroyed in contested territory; and justice and security provision retracts into urban areas and elite enclaves. Conflict causes and compounds poverty. First depleting labour and human capital, then destroying productive assets and financial capital, and finally, eroding the social capital of trust and cooperation upon which strong political and economic systems depend (Mercier et al. 2016). The war economies and institutions that are created in conflict are overwhelmingly extractive, and tend to warp local political economies through their reliance on smuggling and coercion (Keen 1997). These practices can become conflict drivers in their own right, and can perpetuate conflict-related violence and inequality even after war has officially ended (Justino 2013).

Our understanding of the effects of conflict over time is still nascent. Evidence from Burundi suggests that households exposed to violence at the local level are more likely to face long-term poverty and deprivation than those who were spared. Exposure to violence also hurts those who participate in armed groups, as they have to overcome an education deficit, social stigma, and psychological distress that can leave them economically alienated and socially marginalised (Annan et al. 2011). At the country-level, this leads to what some call the 'conflict trap' (Hegre et al. 2011). The strongest predictor of civil war onset is whether a country has recently experienced civil war, with harmful 'neighbourhood effects' making surrounding countries similarly vulnerable to conflict spillover. However, vicious cycles of conflict that exacerbate poverty, slow economic growth, destabilise weak institutions and lead to violent relapse are not inevitable. The international response to post-conflict reconstruction can support a potential 'phoenix effect' of strengthened economic growth, where infrastructure development, debt relief and foreign aid, and currency stabilisation help to generate private investment (Addison et al. 2001; Kang \& Meernik 2005). More importantly, local communities have proven remarkably resilient in rebuilding trust, social cohesion and civic engagement after war ends (Bellows \& Miguel 2009; Blattman 2009; Gilligan et al. 2014; Voors et al. 2012).

\section{Key readings}

Reading 1: Hegre, H., Nygård, H.M., Strand, H., Gates, S., \& Flaten, R.D. (2011). The conflict trap. Annual Meeting of the American Political Science Association, Seattle, September 2011. http://folk.uio.no/hahegre/Papers/ConflictTrapPaper.pdf

This paper provides a valuable introduction to the processes that can lock countries into cycles of poverty and de-development through armed conflict. Although the modelling is technical, it provides a straightforward overview of several key theories and variables in conflict studies (pp. 6-14), and demonstrates the importance of time, conflict intensity, and conflict spillover in shaping short- and long-term effects of war.

Reading 2: Østby, G. (2008). Inequalities, the political environment and civil conflict: evidence from 55 developing countries. In: Horizontal Inequalities and Conflict (ed. F. Stewart). Basingstoke: 
Palgrave Macmillan UK. http://www.gsdrc.org/document-library/horizontal-inequalities-the-politicalenvironment-and-civil-conflict-evidence-from-55-developing-countries/

Building on research led by Frances Stewart (see further reading), Østby's article shows that inequalities between identity groups, are more likely to lead to conflict than individuals in society. She provides an important data-driven response to earlier studies that found no correlation between conflict and ethnic/religious diversity, or inequality.

Reading 3: Humphreys, M., \& Weinstein, J. M. (2008). Who fights? The determinants of participation in civil war. American Journal of Political Science 52(2), 436-455.

http://isites.harvard.edu/fs/docs/icb.topic741392.files/CivilWar.pdf

This survey of ex-combatants in Sierra Leone illustrates fighters' multidimensional motives for participating in conflict. It shows that insurgents and counter-insurgents often have similar profiles including poverty, lack of education, and political alienation. Although it takes a rationalist approach, the article hints at new directions mobilisation research is taking: examining the role of coercion and insecurity, social networks, and variation in recruitment strategies.

Reading 4: Taydas, Z., \& Peksen, D. (2012). Can states buy peace? Social welfare spending and civil conflicts. Journal of Peace Research 49(2), 273-287.

http://jpr.sagepub.com/content/49/2/273.full.pdf+

This article shows that redistributive social policies, particularly for public goods like health and education, can have a strong pacifying effect while also improving economic equality.

Reading 5: Mercier, M., Ngenzebuke, R. L., \& Verwimp, P. (2016). Violence exposure and welfare over time: Evidence from the Burundi civil war. HiCN Working Paper 198. Brighton, UK: Households in Conflict Network, Institute of Development Studies.

http://www.hicn.org/wordpress/wp-content/uploads/2012/06/HiCN-WP-1981.pdf

This analysis illustrates how shifting conflict dynamics affect victims' vulnerability and resilience. It shows that conflict can cause or compound poverty at the household level, and also that education and non-agricultural livelihoods can help households move out of poverty. Expect to see more mixed-methods research on how poverty and conflict shift over time, affecting individuals, households, and communities.

Reading 6: Annan, J., Blattman, C., Mazurana, D., \& Carlson, K. (2011). Civil war, reintegration, and gender in Northern Uganda. Journal of Conflict Resolution 55(6), 877-908.

http://www.chrisblattman.com/documents/research/2011.CivilWarReintegrationGender.JCR.pdf

This article highlights how gender, age, and varying conflict experiences affect post-conflict trajectories for armed group participants. It examines individual outcomes, including the psychological trauma of war, social exclusion, and lost educational and economic opportunities. 
Background Reading: Goodhand, J. (2001) Violent conflict, poverty, and chronic poverty. CPRC Working Paper 6. London: Chronic Poverty Research Centre, ODI.

http://www.chronicpoverty.org/uploads/publication_files/WP06_Goodhand.pdf

For those new to studies of poverty and conflict, Goodhand provides a useful primer to key concepts, as well as an overview of the international policy discourse in 2000.

\section{Questions to guide reading}

1. Why are poor countries more conflict-prone?

2. Is it poverty or inequality that leads to conflict?

3. In what ways are poor people more vulnerable to conflict-related violence?

4. How do gender, age, and other factors shape people's experiences of poverty and conflict?

5. What are the short-term and long-term effects of conflict on economic, human, and social capital?

6. Is there a poverty-conflict trap? If so, how can it be broken?

\section{Further reading}

Addison, T., Geda, A., Le Billon, P., \& Murshed, S. M. (2001). Financial reconstruction in conflict and "post-conflict" economies. UNU/WIDER Discussion Paper 2001/90. Helsinki: UNU-WIDER.

https://core.ac.uk/download/pdf/6484109.pdf

Blattman, C. (2009). From violence to voting: War and political participation in Uganda. American Political Science Review, 103(02), 231-247.

http://www.chrisblattman.com/documents/research/2009.V2V.APSR.pdf

Blattman, C., \& Miguel, E. (2010). Civil war. Journal of Economic Literature, 48(1), 3-57.

http://chrisblattman.com/documents/research/2010.CivilWar.JEL.pdf

De Ree, J., \& Nillesen, E. (2009). Aiding violence or peace? The impact of foreign aid on the risk of civil conflict in sub-Saharan Africa. Journal of Development Economics 88(2), 301-313.

http://www.diw.de/documents/dokumentenarchiv/17/90684/diwpublication_de_enillesen.pdf

Fearon, J. D., \& Laitin, D. D. (2003). Ethnicity, insurgency, and civil war. American Political Science Review 97(01): 75-90.

http://fsi.stanford.edu/publications/ethnicity_insurgency_and_civil_war

Justino, P. (2013). Research and policy implications from a micro-level perspective on the dynamics of conflict, violence, and development. HiCN Working Paper 139. Brighton, UK: Households in Conflict Network, Institute of Development Studies.

http://www.hicn.org/wordpress/wp-content/uploads/2012/06/HiCN-WP-139.pdf

Nielsen, R. A., Findley, M. G., Davis, Z. S., Candland, T., \& Nielson, D. L. (2011). Foreign aid shocks as a cause of violent armed conflict. American Journal of Political Science 55(2), 219-232.

http://www.mit.edu/ rnielsen/Nielsen\%20et\%20al\%202011.pdf 
Ross, M. L. (2004). What do we know about natural resources and civil war?. Journal of Peace Research, 41(3), 337-356.

https://www.researchgate.net/profile/Michael_Ross11/publication/248418789_What_Do_We_Know_about_ Natural_Resources_and_Civil_War/links/0f31752d9575c1499d000000.pdf

Savun, B., \& Tirone, D. C. (2011). Foreign aid, democratization, and civil conflict: how does democracy aid affect civil conflict?. American Journal of Political Science 55(2), 233-246.

Available at SSRN: https://ssrn.com/abstract=1456753

Stewart, F. (2009). Horizontal inequalities as a cause of conflict. Bradford Development Lecture, University of Bradford, November 2009.

http://www.bradford.ac.uk/social-sciences/media/socialsciences/BDLStewart.pdf

Thies, C. G. (2010). Of rulers, rebels, and revenue: State capacity, civil war onset, and primary commodities. Journal of Peace Research, 47(3), 321-332.

https://www.researchgate.net/profile/Cameron_Thies/publication/227574656_Of_Rulers_Rebels_and_Reven ue_State_Capacity_Civil_War_Onset_and_Primary_Commodities/links/550850790cf2d7a281284ec8.pdf

Voors, M. J., Nillesen, E. E., Verwimp, P., Bulte, E. H., Lensink, R., \& Van Soest, D. P. (2012). Violent conflict and behavior: A field experiment in Burundi. The American Economic Review 102 (2), 941964.

https://www.aeaweb.org/articles?id=10.1257/aer.102.2.941 